\title{
Vitamin C increases 5-hydroxymethylcytosine level and inhibits the growth of bladder
} cancer

\author{
Ding Peng 1,2,3,4, $\mathbb{D}_{\text {, Guangzhe Ge }}^{2,6}$, Yanqing Gong 1,3,4, , Yonghao Zhan 1,3,4,5, Shiming He $\mathrm{He}^{1,3,4,5}$, Bao Guan 1,3,4,5,

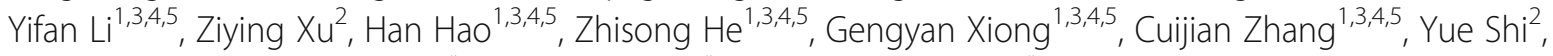 \\ Yuanyuan Zhou ${ }^{2}$, Weimin $\mathrm{Ci}^{2,6^{*}}$, Xuesong $\mathrm{Li}^{1,3,4,5^{*}}$ and Liqun Zhou ${ }^{1,3,4,5^{*}}$
}

\begin{abstract}
Background: 5 -Hydroxymethylcytosine $(5 \mathrm{hmC})$ is converted from 5-methylcytosine $(5 \mathrm{mC})$ by a group of enzymes termed ten-eleven translocation (TET) family dioxygenases. The loss of $5 \mathrm{hmC}$ has been identified as a hallmark of most types of cancer and is related to tumorigenesis and progression. However, the role of $5 \mathrm{hmC}$ in bladder cancer is seldom investigated. Vitamin C was recently reported to induce the generation of $5 \mathrm{hmC}$ by acting as a cofactor for TET dioxygenases. In this study, we explored the role of $5 \mathrm{hmC}$ in bladder cancer and the therapeutic efficacy of vitamin $\mathrm{C}$ in increasing the $5 \mathrm{hmC}$ pattern.

Results: $5 \mathrm{hmC}$ was decreased in bladder cancer samples and was related to patient overall survival. Genome-wide mapping of $5 \mathrm{hmC}$ in tumor tissues and vitamin C-treated bladder cancer cells revealed that $5 \mathrm{hmC}$ loss was enriched in cancer-related genes and that vitamin C treatment increased $5 \mathrm{hmC}$ levels correspondingly. Vitamin $\mathrm{C}$ treatment shifted the transcriptome and inhibited the malignant phenotypes associated with bladder cancer cells in both in vitro cell lines and in vivo xenografts.

Conclusions: This study provided mechanistic insights regarding the $5 \mathrm{hmC}$ loss in bladder cancer and a rationale for exploring the therapeutic use of vitamin $C$ as a potential epigenetic treatment for bladder cancer.
\end{abstract}

Keywords: Bladder cancer, 5-Hydroxymethylcytosine, Vitamin C, TET

\section{Background}

Bladder cancer is the most common cancer of the urogenital system, ranking sixth among all cancers and fourth in males $[1,2]$. Despite the advancements in surgical techniques and chemotherapy, the outcome of bladder cancer is still poor, especially in patients with advanced and metastatic disease [3]. Therefore, there is a pressing need for novel biomarkers that can stratify the risk of mortality and provide potential therapeutic targets.

Alterations in DNA methylation are among the earliest and most common events in tumorigenesis [4]. Global loss and promoter-associated gains of DNA methylation

\footnotetext{
*Correspondence: ciwm@big.ac.cn; pineneedle@sina.com;

zhoulqmail@sina.com

${ }^{2}$ Key Laboratory of Genomic and Precision Medicine, Beijing Institute of Genomics, Chinese Academy of Sciences, Beijing 100101, China

'Department of Urology, Peking University First Hospital, Beijing 100034, China Full list of author information is available at the end of the article
}

(5-methylcytosine, $5 \mathrm{mC}$ ) have been considered to be the hallmarks of cancers [5-7]. Recently, 5-hydroxymethylcytosine $(5 \mathrm{hmC})$ was discovered as a transformed form of $5 \mathrm{mC}$ via ten-eleven translocation (TET) enzymes in the demethylation cycle [8]. In a number of cancers, $5 \mathrm{hmC}$ has been observed to be remarkably decreased and associated with tumorigenesis, progression, and outcomes [9-12].

Several studies have also reported the loss of $5 \mathrm{hmC}$ in bladder cancer [13, 14]. However, the genome-wide profile and role of $5 \mathrm{hmC}$ in bladder cancer tumorigenesis, progression, and outcome have been seldom investigated. Vitamin $\mathrm{C}$ is a co-substrate of $\mathrm{Fe}$ (II)-2-oxoglutarate-dependent dioxygenases, including TETs [15]. Recently, vitamin $C$ was reported to block leukemia progression and promote differentiation by enhancing $5 \mathrm{hmC}$ formation $[16,17]$.

Here, we compared the $5 \mathrm{hmC}$ genome-wide profiles between normal bladder and bladder cancer tissues and

(C) The Author(s). 2018 Open Access This article is distributed under the terms of the Creative Commons Attribution 4.0 International License (http://creativecommons.org/licenses/by/4.0/), which permits unrestricted use, distribution, and 
characterized the association between $5 \mathrm{hmC}$ and bladder cancer tumorigenesis, progression, and outcomes. We showed that vitamin $\mathrm{C}$ could increase $5 \mathrm{hmC}$ levels and inhibit malignant phenotypes in bladder cancer both in vitro and in vivo. Loss of $5 \mathrm{hmC}$ could be a novel biomarker and treatment target for bladder cancer.

\section{Results}

$5 \mathrm{hmC}$ level is an independent molecular marker of bladder cancer

We first detected $5 \mathrm{hmC}$ levels in normal bladder and bladder cancer tissues by immunohistochemistry (IHC) staining with formalin-fixed, paraffin-embedded tissue sections. The clinicopathological characteristics of 135 patients with bladder urothelial carcinoma are shown in Table 1. Consistent with recent findings in other types of cancers, normal bladder tissues showed strong nuclear $5 \mathrm{hmC}$ staining $(n=135)$, whereas bladder cancer showed a partial or complete loss of $5 \mathrm{hmC}(n=135)(P<0.05$, Fig. 1a, b; normal renal tissue was used as a positive control). The loss of $5 \mathrm{hmC}$ was also confirmed by anti-5hmC antibody-based dot blot assay in matched bladder cancer and normal bladder tissues (Fig. 1c). A Kaplan-Meier log-rank test revealed that patients with higher $5 \mathrm{hmC}$ levels had significantly longer overall survival than patients with lower $5 \mathrm{hmC}$ levels (Fig. 1d). Further, univariate and multivariate Cox proportional hazard regression analyses showed that the $5 \mathrm{hmC}$ level in tumor tissues independently provided predictive power and that lower $5 \mathrm{hmC}$ levels correlated with

Table 1 Clinicopathological characteristics of 135 patients with bladder urothelial carcinoma

\begin{tabular}{ll}
\hline Characteristics & Total $n=135$ \\
\hline Age, years, median (IQR) & $66(56-74)$ \\
Gender & 23 \\
female & 112 \\
male & \\
Grade & 35 \\
2 & 100 \\
3 & \\
T stage & 3 \\
Tis & 36 \\
T1 & 39 \\
T2 & 25 \\
T3 & 32 \\
T4 & \\
N status & 110 \\
Negative & 25 \\
Positive & \\
\hline
\end{tabular}

IQR interquartile range shorter overall survival, as reflected by the hazard ratio of 0.483 (Fig. 1e), suggesting that the loss of $5 \mathrm{hmC}$ is critical for bladder cancer progression. Meanwhile, a lower $5 \mathrm{hmC}$ level was also associated with a higher tumor stage and lymphatic metastasis (Table 2).

\section{Genome-wide mapping of $5 \mathrm{hmC}$ in paired tumor and adjacent normal tissue}

To explore whether $5 \mathrm{hmC}$ loss during bladder tumorigenesis was genome-wide or locus-specific, we used a hydroxymethylated DNA immunoprecipitation (hMeDIP) approach coupled with deep sequencing (hMeDIP-seq) to compare genome-wide changes in $5 \mathrm{hmC}$ between the normal bladder and bladder cancer tissue. We found that $5 \mathrm{hmC}$ is associated with gene-rich regions in the normal bladder genome and is relatively low in the bladder cancer genome (Fig. 2a). Importantly, we observed a significant decrease in $5 \mathrm{hmC}$ levels within the average gene and in the regions 2000 bp up- and downstream of the gene in bladder cancer tissue compared with normal bladder tissue (Fig. 2b). Using MACS software, we identified 27,565 $5 \mathrm{hmC}$ peaks that were decreased in bladder cancer $($ FDR $<0.05)$, more than half of which were located either in exons $(10.3 \%)$ or introns $(58.9 \%)$ and $6.45 \%$ of which were located at the promoters (Fig. 2c). Using CEAS software, $27,5655 \mathrm{hmC}$ peaks were mapped to 5843 genes. KEGG pathway enrichment and GO term analyses of the 5843 genes revealed that these genes are closely associated with various cancer-related pathways (Fig. 2d). As an example, the TIMP2 and ITIH5 genes showed decreased $5 \mathrm{hmC}$ in gene bodies in bladder cancer compared with the normal bladder samples, and hMeDip-qPCR/ MeDip-qPCR verified the increase in $5 \mathrm{hmC}$ and a relative decrease in $5 \mathrm{mC}$ (Fig. 2e). Collectively, the loss of $5 \mathrm{hmC}$ occurred in multiple cancer-related genes during bladder carcinogenesis.

\section{Increasing $5 \mathrm{hmC}$ by vitamin $\mathrm{C}$ can inhibit the malignant phenotype of bladder cancer cells}

We next detected the $5 \mathrm{hmC}$ levels in normal and bladder cancer cell lines. According to dot blot assay, $5 \mathrm{hmC}$ content was relatively high in nonmalignant cells (primary urothelial cells Hum-u007 and immortalized normal cells SV-HUC-1) but was low in bladder cancer cells (Fig. 3a). To explore the molecular mechanisms underlying $5 \mathrm{hmC}$ loss in bladder cancer, we also measured the expression of $5 \mathrm{hmC}$-related enzymes (TET1, TET2, TET3, IDH1, IDH2, and L2HGDH) and vitamin $\mathrm{C}$ transporters (SVCT1 and SVCT2) by RT-qPCR and found that the expression of TET2, L2HGDH, and vitamin C transporters (SVCT1 and SVCT2) were relatively decreased in all bladder cancer cell lines (Fig. 3b). Vitamin $\mathrm{C}$ is capable of increasing $5 \mathrm{hmC}$ by acting as a cofactor of TET proteins. We then treated several bladder 

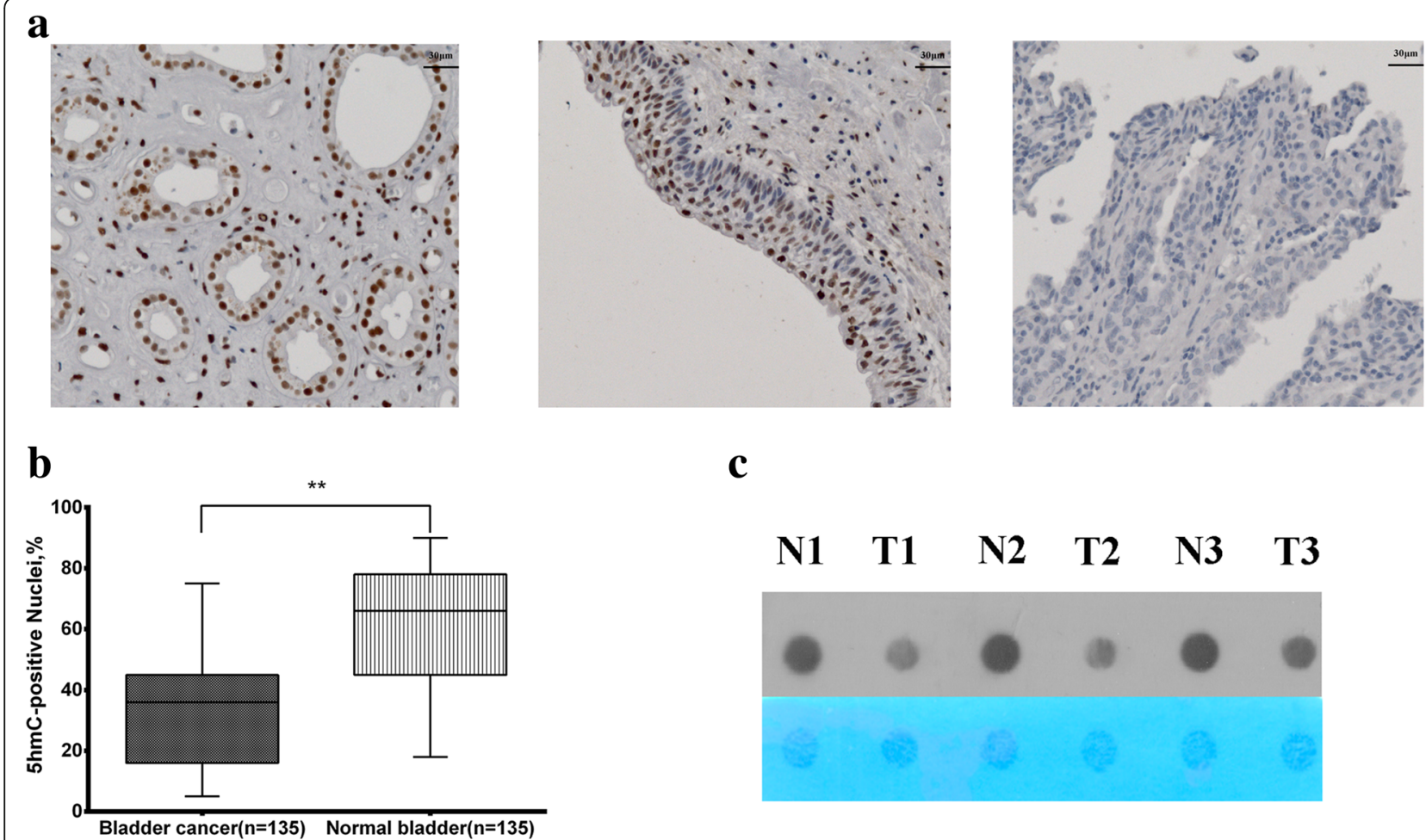

C
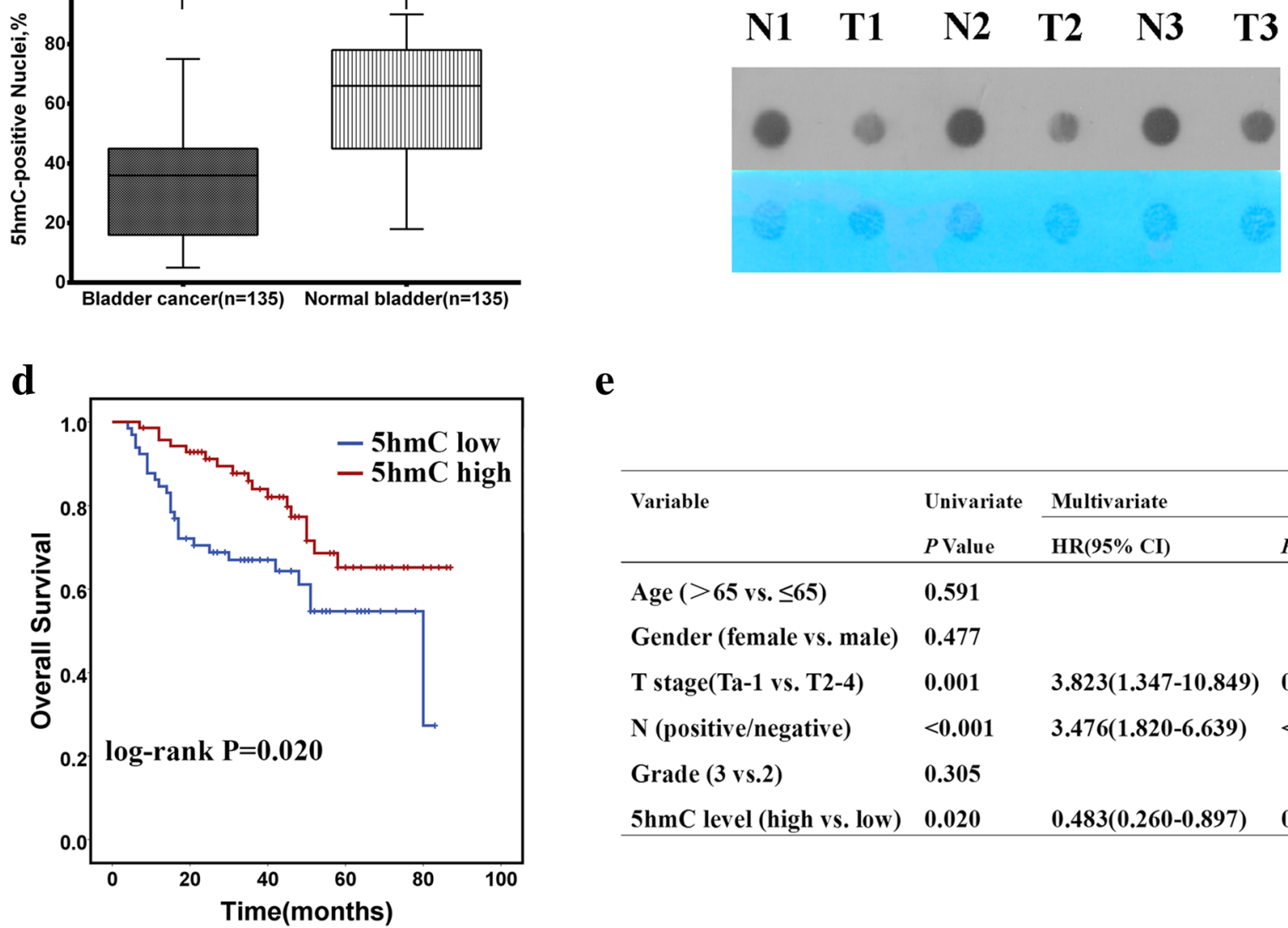

$\mathbf{e}$

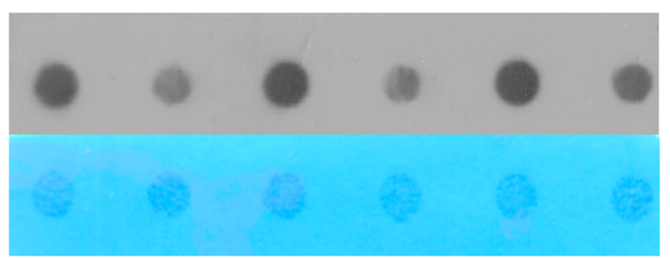

\begin{tabular}{llll}
\hline Variable & Univariate & Multivariate & \\
\cline { 3 - 4 } & $P$ Value & HR(95\% CI) & $P$ Value \\
\hline Age (>65 vs. $\leq 65)$ & 0.591 & & \\
Gender (female vs. male) & 0.477 & & \\
T stage(Ta-1 vs. T2-4) & 0.001 & $3.823(1.347-10.849)$ & 0.012 \\
N (positive/negative) & $<0.001$ & $3.476(1.820-6.639)$ & $<0.001$ \\
Grade (3 vs.2) & 0.305 & & \\
5hmC level (high vs. low) & 0.020 & $0.483(0.260-0.897)$ & 0.021 \\
\hline
\end{tabular}

Fig. 1 Loss of $5 \mathrm{hmC}$ is a hallmark of bladder cancer. a IHC staining of $5 \mathrm{hmC}$ in the positive control (normal kidney) and representative bladder cancer and normal bladder samples. Scale bar, $30 \mu \mathrm{m}$. b Analysis of $5 \mathrm{hmC}$ levels in bladder cancer and normal bladder samples represented by a $5 \mathrm{hmC}$ score. Statistical significance was determined by the Mann-Whitney $U$ test. c Dot blot assay of $5 \mathrm{hmC}$ levels in normal bladder tissues relative to bladder cancer tissues. $\mathbf{d}$ Kaplan-Meier survival curves of bladder cancer patients with high and low $5 \mathrm{hmC}$ staining. $P$ value was calculated by the log-rank test. e Multivariate Cox regression analyses of bladder cancer cases

cancer cell lines with vitamin $C$ at varying concentrations and time periods. As a result, vitamin $\mathrm{C}$ increased the $5 \mathrm{hmC}$ levels in $\mathrm{T} 24$ cells in a time- and concentration-dependent manner (Fig. 3c). Meanwhile, global $5 \mathrm{mC}$ levels were slightly decreased (Fig. 3d). J82 and 5637 cells showed similar results (Additional file 1: Figure S1B and C). Moreover, we observed similar effects with vitamin $\mathrm{C}$, which increased $5 \mathrm{hmC}$ levels and inhibited cancer cell growth in renal cancer cells (Additional file 1: Figure S1D). We also measured relative TET1/2/3 expression levels after vitamin $C$ treatment by RT-qPCR and found no significant changes (Additional file 2: Figure S2A). This result indicated that vitamin $\mathrm{C}$ increases $5 \mathrm{hmC}$ levels in bladder cancer cells 
Table 2 Association between clinicopathological characteristics and $5 \mathrm{hmC}$ level of bladder urothelial carcinoma

\begin{tabular}{lllc}
\hline $\begin{array}{l}\text { Cohort } \\
\text { characteristics }\end{array}$ & \multicolumn{2}{c}{ 5hmc level } & \multicolumn{2}{c}{$\begin{array}{c}\text { Chi-square test } \\
P \text { value }\end{array}$} \\
\cline { 2 - 3 } Grade & Low & High & 0.514 \\
2 & 20 & 18 & \\
3 & 45 & 52 & 0.412 \\
Age & & & \\
$<65$ & 27 & 34 & 0.010 \\
$\geq 65$ & 38 & 36 & \\
T stage & & & \\
Tis-T1 & 12 & 27 & 0.028 \\
T2-T4 & 53 & 43 & \\
N stage & & & \\
Negetive & 47 & 62 & \\
Positive & 18 & 8 & \\
\hline
\end{tabular}

by promoting the activity of TET enzymes rather than by increasing the expression levels. In the cell proliferation analysis by MTS assay at varying concentrations, vitamin $C$ significantly inhibited bladder cancer cell proliferation at pharmacological concentrations (0.5 to $5 \mathrm{mM}$ ), although it was relatively less toxic to nonmalignant cells (Fig. 3e). High-dose vitamin $\mathrm{C}$ also induced significant apoptosis in T24 cells (Fig. 3f and Additional file 2: Figure S2B). Colony formation assays also demonstrated the inhibitory effects of vitamin $C$ in bladder cancer cells relative to nonmalignant cells (Fig. 3g). It was reported that high-dose vitamin $\mathrm{C}$ can inhibit cancer cells by $\mathrm{H}_{2} \mathrm{O}_{2}$ production. To eliminate the influence of $\mathrm{H}_{2} \mathrm{O}_{2}$, we added $100 \mu \mathrm{g} / \mathrm{ml}$ catalase to block all $\mathrm{H}_{2} \mathrm{O}_{2}$ and found that the inhibition of high-dose vitamin $\mathrm{C}$ was partially rescued; however, vitamin $C$ still had a suppression effect (Additional file 2: Figure S2C). In summary, high-dose vitamin $C$ could directly induce growth arrest and apoptosis in bladder cancer cells, unlike low-dose vitamin $\mathrm{C}$, which suppressed cancer cell growth in an $\mathrm{H}_{2} \mathrm{O}_{2}$-independent manner that included $5 \mathrm{hmC}$ restoration.

Additionally, an intraperitoneal injection of $2 \mathrm{~g} / \mathrm{kg} / \mathrm{day}$ vitamin $C$ induced slower growth and a smaller tumor burden than saline in vivo without significant toxicity or weight loss (Fig. 4a-d). IHC staining also revealed increased $5 \mathrm{hmC}$ levels in the vitamin $\mathrm{C}$ treatment group (Fig. 4e). Collectively, our results support that vitamin $\mathrm{C}$ can increase $5 \mathrm{hmC}$ levels and block bladder cancer growth.

\section{Vitamin C can re-establish the $5 \mathrm{hmC}$ landscape in bladder cancer cells}

We next explored the re-established pattern of $5 \mathrm{hmC}$ with vitamin $\mathrm{C}$ treatment. T24 cells treated with
$0.25 \mathrm{mM}$ vitamin $\mathrm{C}$ or without treatment (control) were used to profile genome-wide $5 \mathrm{hmC}$ patterns by hMeDIP-seq. We found that vitamin C-treated bladder cancer cells showed re-establishment of the $5 \mathrm{hmC}$ landscape, which was similar to the landscape of normal bladder tissues (Fig. 5a). Using MACS software, 28,015 $5 \mathrm{hmC}$ peaks and 6809 mapped genes were identified. KEGG pathway enrichment and GO term analyses of the 6809 genes revealed that these genes were closely associated with various cancer-related pathways (Fig. 5b). By overlapping the $5 \mathrm{hmC}$ profiles from normal tissues and vitamin C-treated T24 cells, we identified 2511 RefSeq genes with decreased $5 \mathrm{hmC}$ densities in bladder cancer tissue that were restored by vitamin $C$ treatment in T24 cells. KEGG pathway and GO term analyses revealed that these genes were mainly associated with adhesion and cancer-related genes (Fig. 5c, d). As exemplified by the LATS2 and RND3 genes, vitamin C restored $5 \mathrm{hmC}$ levels in T24 cells; these levels were relatively low in bladder cancer cells compared with normal bladder cells, and $5 \mathrm{mC}$ showed an opposite trend (Fig. 5e). We further mapped these $28,0155 \mathrm{hmC}$ peaks to different elements and found that the peaks were more enriched in the enhancers, exons, and promoters than in introns and intergenic regions (Fig. 5b). It was reported that $5 \mathrm{hmC}$ in the enhancer regions is associated with gene expression [18]. We identified 154 enhancers that overlapped with vitamin C-increased $5 \mathrm{hmC}$ peaks. IPA analysis of the 382 enhancer-assigned genes showed that the most significantly enriched pathways were cancer-related pathways, such as NRF2-mediated oxidative stress response, TNFR2 signaling, RhoA signaling, and IL-1 signaling.

\section{Vitamin C treatment shifted the transcriptome of bladder cancer cells}

We next examined the phenotypic changes in T24 cells at the global transcriptome level after treatment with $0.25 \mathrm{mM}$ vitamin C. Using DEseq2, 1172 differentially expressed genes were identified, including 482 upregulated and 690 downregulated genes (Fig. 6a and Additional file 3: Table S1). KEGG pathway and GO term analyses showed that these genes were mainly associated with focal adhesion, DNA replication, cell cycle, and several cancer-related pathways (Fig. 6b, c and Additional file 4: Table S2). Gene set enrichment analysis (GSEA) analysis also showed an inhibitory effect on the cell cycle and DNA replication (Fig. 6d). Furthermore, among the 1172 genes, 503 genes overlapped with the 6809 restored $5 \mathrm{hmC}$-related genes (Fig. 6e). KEGG pathway analysis of these 503 genes also showed enriched focal adhesion and several cancer-related pathways (Fig. 6f). We overlapped these 1172 genes with the genes that showed decreased 


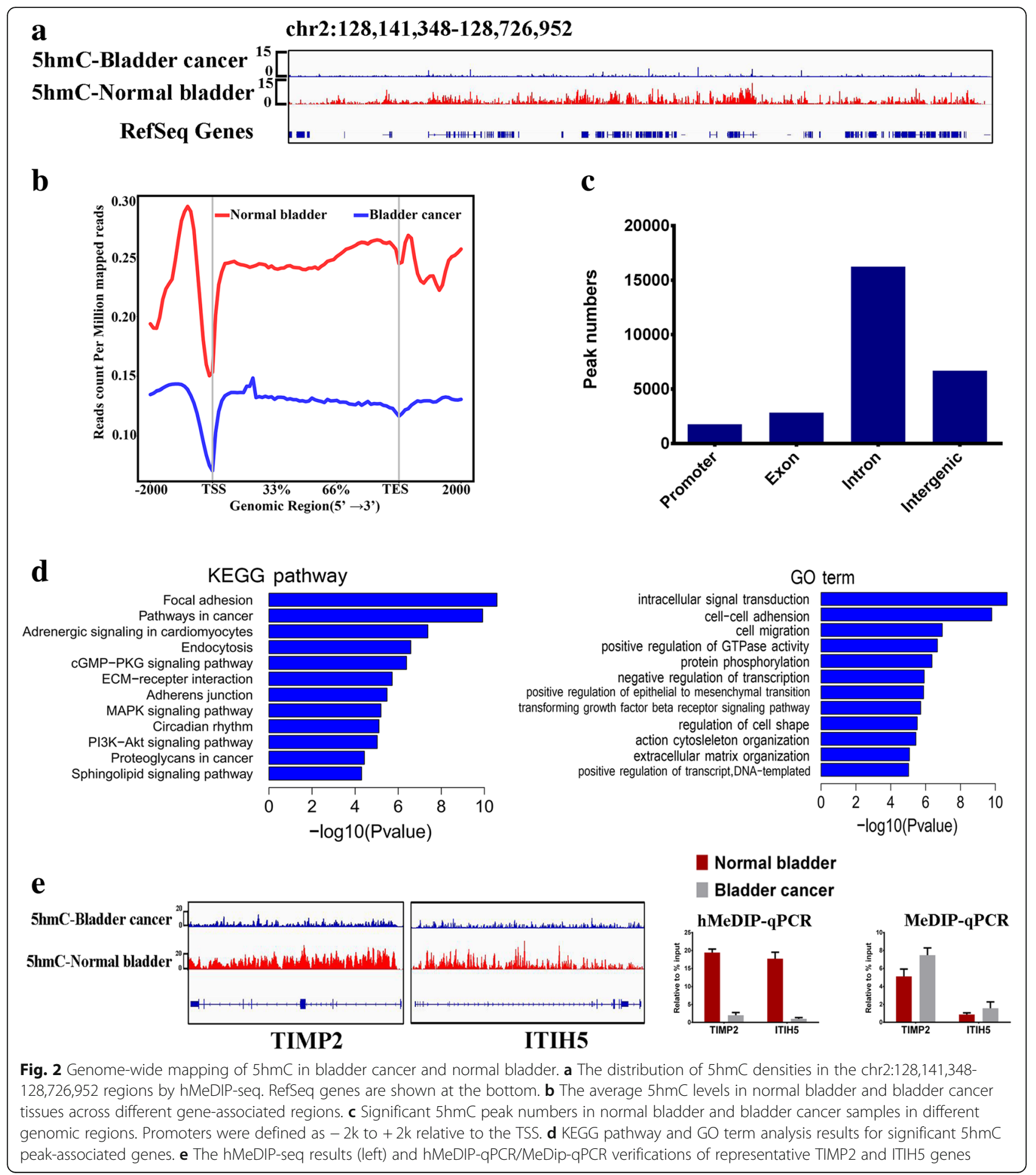

$5 \mathrm{hmC}$ in bladder cancer tissue, and 499 genes were identified as common to both sets. KEGG pathway analysis of these 499 genes also showed enriched focal adhesion and several cancer-related pathways (Additional file 2: Figure S2D). Furthermore, we intersected three sets of genes (genes with decreased $5 \mathrm{hmC}$ in bladder cancer tissue, genes with increased $5 \mathrm{hmC}$ after vitamin C treatment, and 1172 differently expressed genes) and found 265 overlapping genes. KEGG pathway analysis of these 265 genes showed enriched focal adhesion and several cancer-related pathways (Additional file 2: Figure S2E). Therefore, vitamin $C$ treatment shifted the transcriptome of bladder cancer cells to inhibit malignant phenotypes. 
$\mathbf{a}$

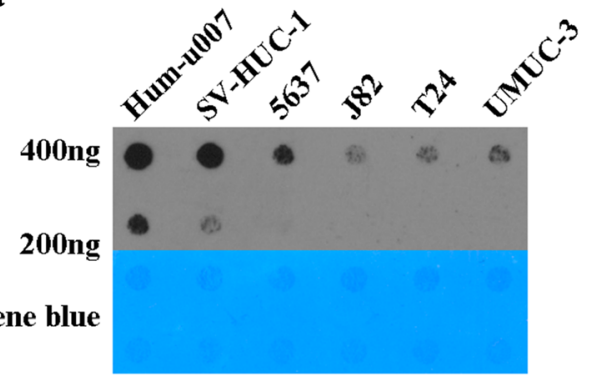

c $\begin{array}{lllllllll}0 & 0.1 & 0.25 & 0.5 & (\mathrm{mM}) & 0 \mathrm{~h} & 6 \mathrm{~h} & 12 \mathrm{~h} & 24 \mathrm{~h}\end{array}$

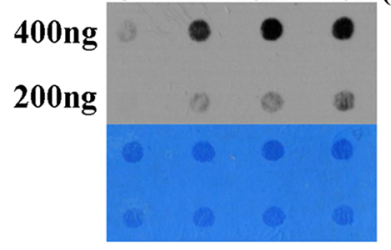

e

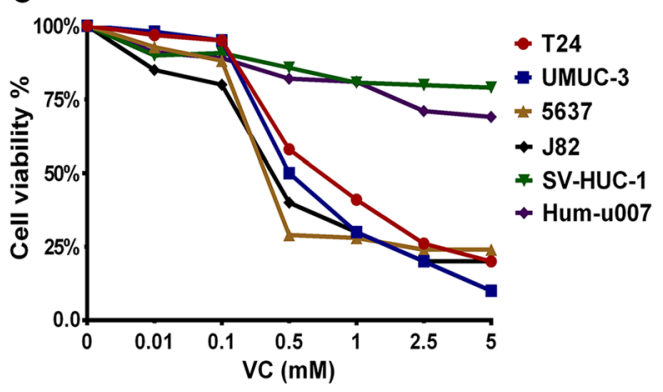

g
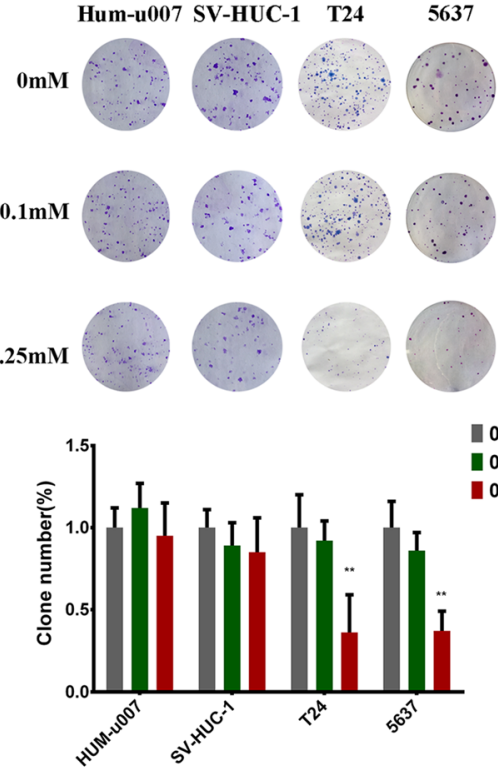

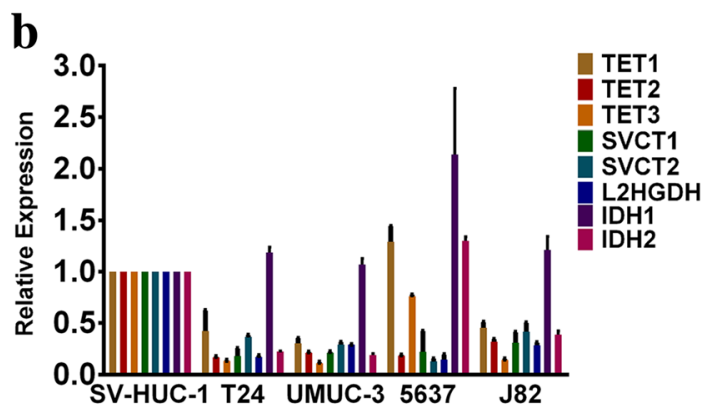

d

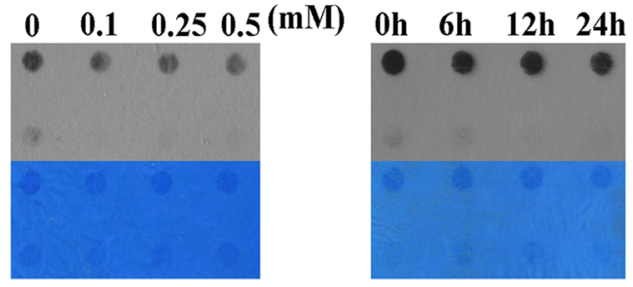

f
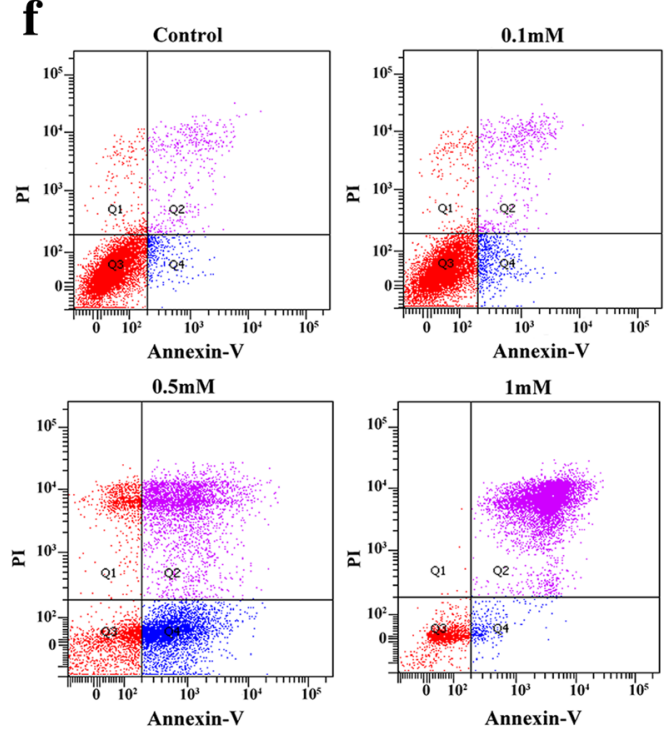

necrosis

Normal cells

- Apoptosis

- Late apoptosis

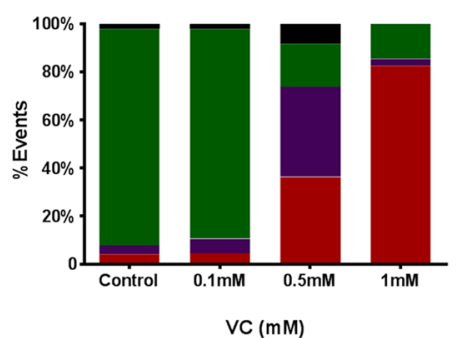

Fig. 3 (See legend on next page.) 
(See figure on previous page.)

Fig. 3 Vitamin C treatment increases 5hmC levels and decreases malignant phenotypes in bladder cancer cells in vitro. a Dot blot assay of 5hmC levels in normal bladder and cancer cell lines. $\mathbf{b}$ The relative transcription levels measured by RT-qPCR of 5hmC-related genes and SVCTs in normal bladder and bladder cancer cells. c Dot blot assay of $5 \mathrm{hmC}$ levels of T24 cells at varying concentrations and time periods with vitamin C. $\mathbf{d}$ Dot blot assay of $5 \mathrm{mC}$ levels of T24 cells at varying concentrations and time periods with vitamin C. e MTS assay of cell viability for normal bladder and cancer cell lines at varying concentrations with vitamin C. f Apoptosis assay of T24 cells at varying concentrations with vitamin C. $\mathbf{g}$ Clone formation assay for normal bladder and cancer cell lines at varying concentrations with vitamin C. Statistical significance was determined by the Mann-Whitney $U$ test

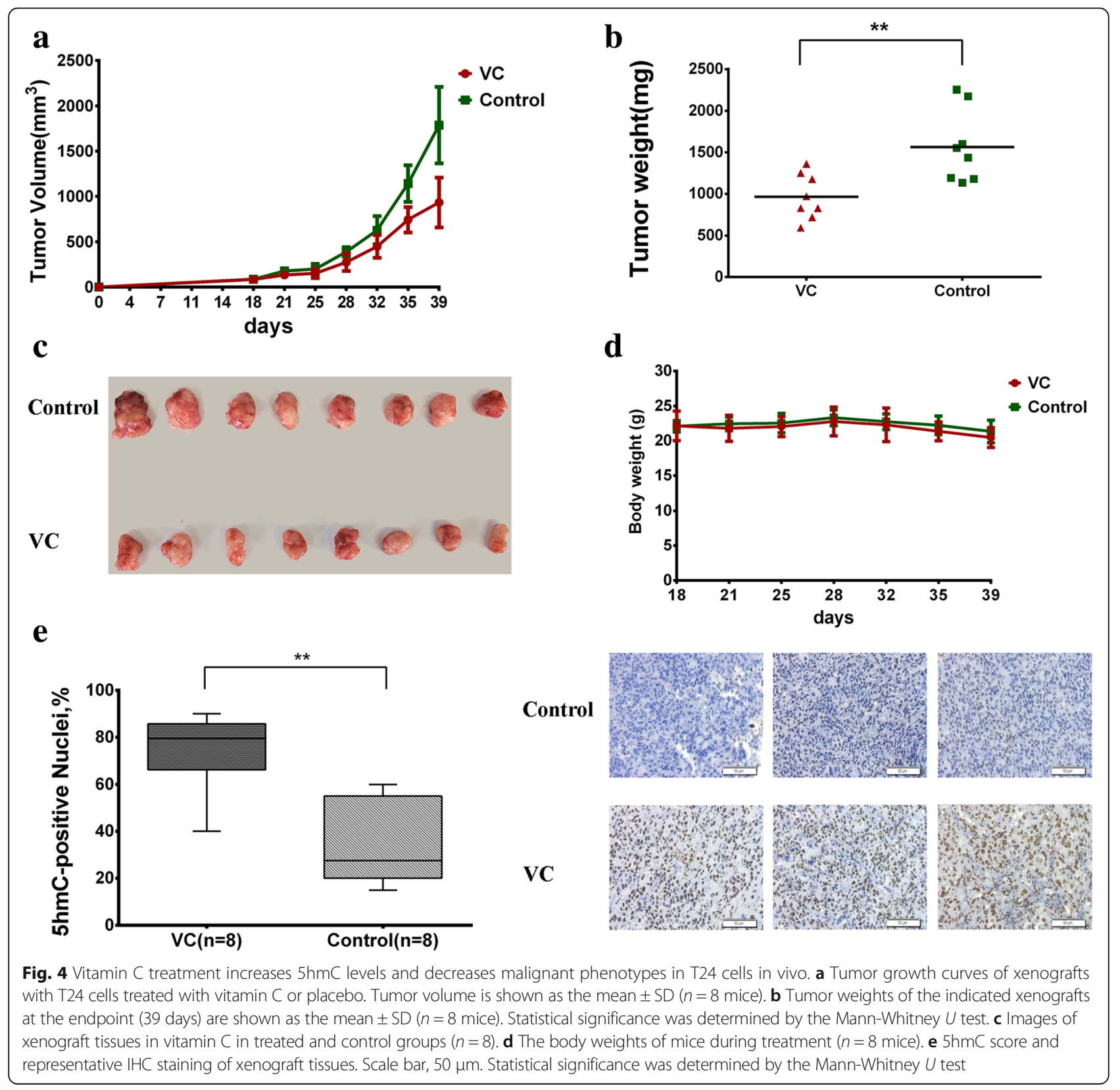




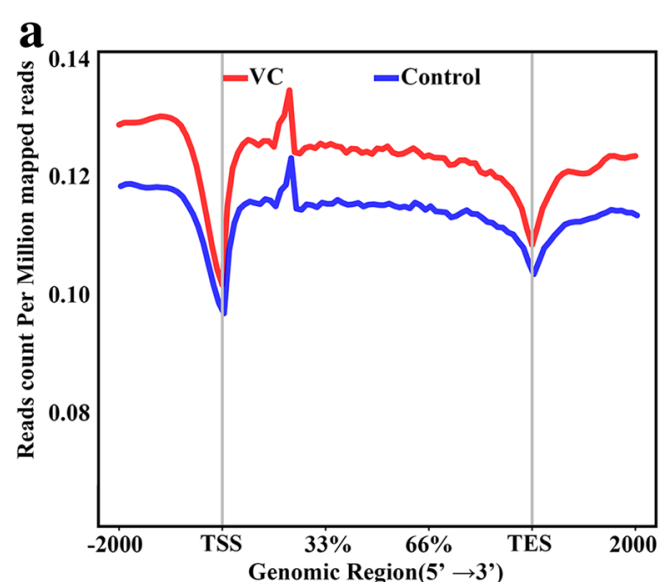

C

KEGG pathway

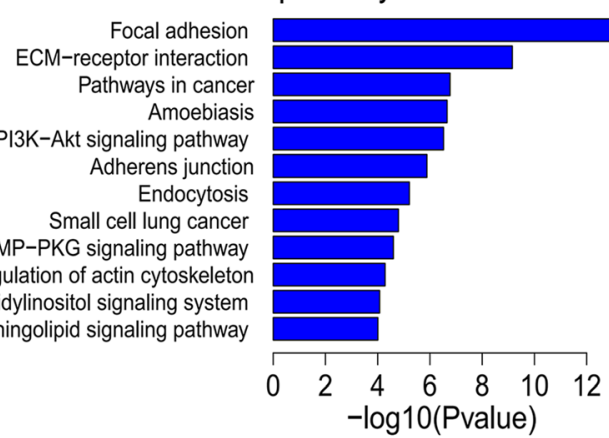

b

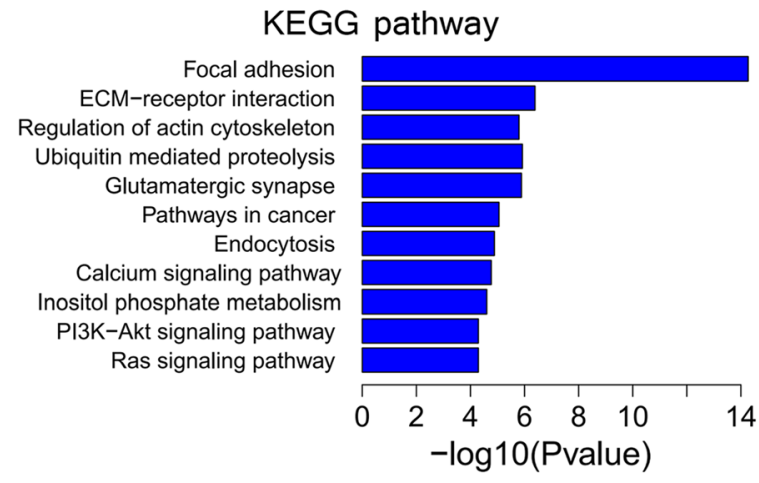

d

\section{GO term}

positive regulation of cell-cell adhesion intracellular signal transduction peptidyl-serine phosphorylation protein phosphorylation signal transduction cell migration

regulation of Rho protein signal transduction actin cytoskeleton organization extracellular matrix organization endocytosis

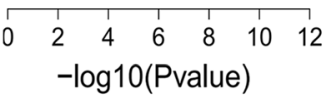

$-\log 10$ (Pvalue)

\section{e}

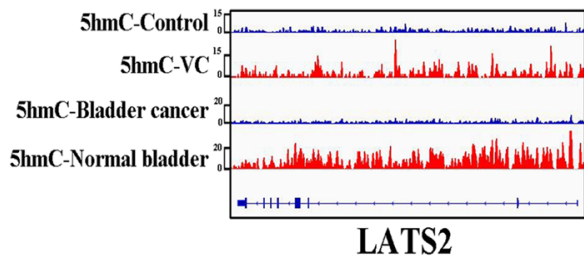

f

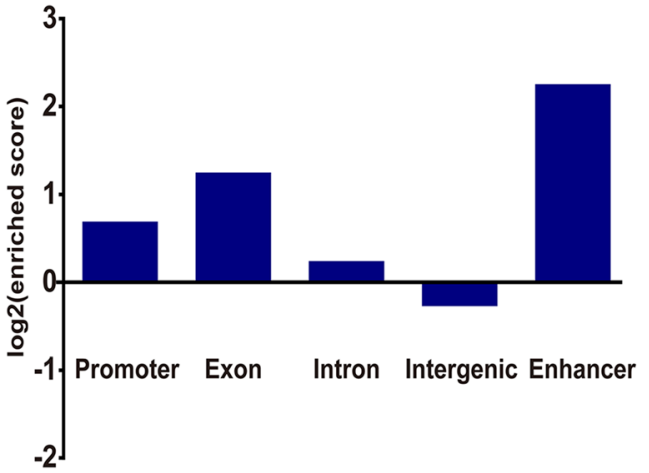

g

IPA pathway enrichment

NRF2-mediated Oxidative Stress Response

TNFR2 Signaling

RhoA Signaling

UDP-N-acetyl-D-galactosamine Biosynthesis II

IL-1 Signaling

RhoGDI Signaling

Chemokine Signaling

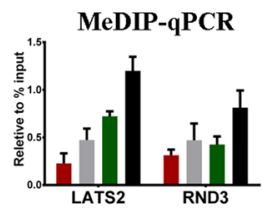


(See figure on previous page.)

Fig. 5 Vitamin C treatment re-establishes the $5 \mathrm{hmC}$ landscape in the bladder cancer cell epigenome. a Average $5 \mathrm{hmC}$ levels in T24 cells treated with vitamin C or control across different gene-associated regions. b KEGG pathway analysis results for significantly elevated $5 \mathrm{hmC}$ peak-associated genes. c KEGG pathway analysis results for overlapping $5 \mathrm{hmC}$ peak-associated genes. $\mathbf{d} \mathrm{GO}$ term analysis results for overlapping $5 \mathrm{hmC}$ peak-associated genes. e The hMeDIP-seq results and hMeDIP-qPCR/MeDip-qPCR verifications of representative overlapping LATS2 and RND3 genes. $\mathbf{f}$ The enrichment scores of vitamin C-restored $5 \mathrm{hmC}$ peaks in different genomic elements. $\mathbf{g}$ IPA pathway enrichment analysis for enhancer-assigned genes

\section{Discussion}

In this study, we illustrated the genome-wide profile of $5 \mathrm{hmC}$ loss in bladder cancer and the prognostic value of global $5 \mathrm{hmC}$ levels. Furthermore, we found that vitamin $\mathrm{C}$ increased $5 \mathrm{hmC}$ content and inhibited the malignant phenotypes associated with bladder cancer. Our results showed that the loss of $5 \mathrm{hmC}$ and $5 \mathrm{hmC}$ restoration by vitamin $\mathrm{C}$ were significantly associated with cancer-related genes.

$5 \mathrm{hmC}$ was first discovered in the 1970 s and has received renewed attention in the last decade for its involvement in the regulation of embryonic stem (ES) cell differentiation and nervous system development $[19,20]$. The loss of $5 \mathrm{hmC}$ has been identified as a novel $\mathbf{a}$

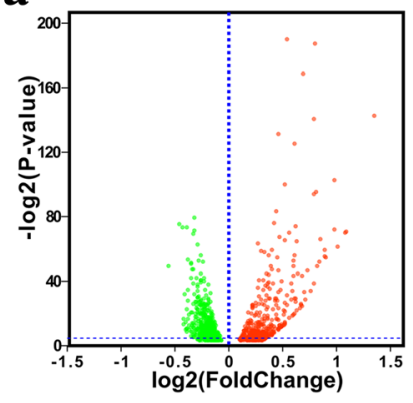

C

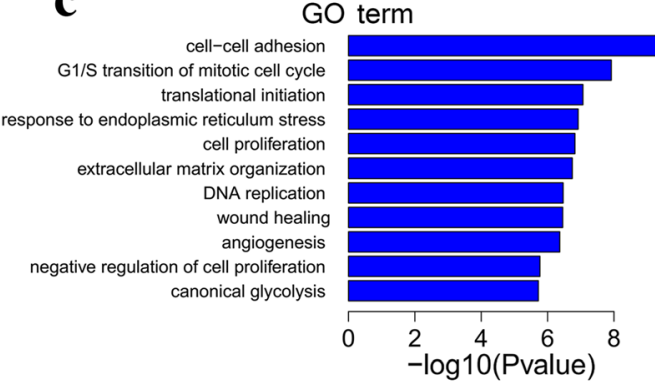

\section{b}

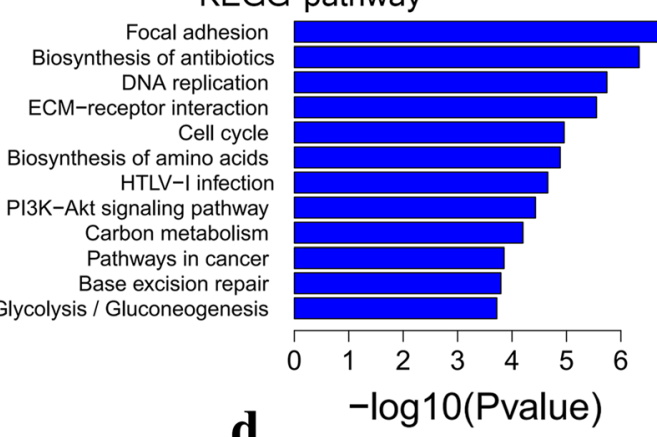

d

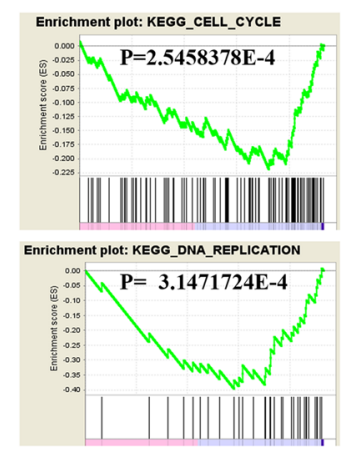

$\mathbf{e}$

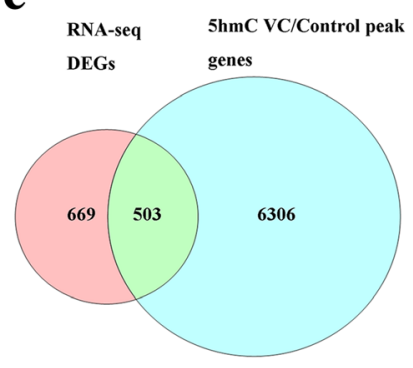

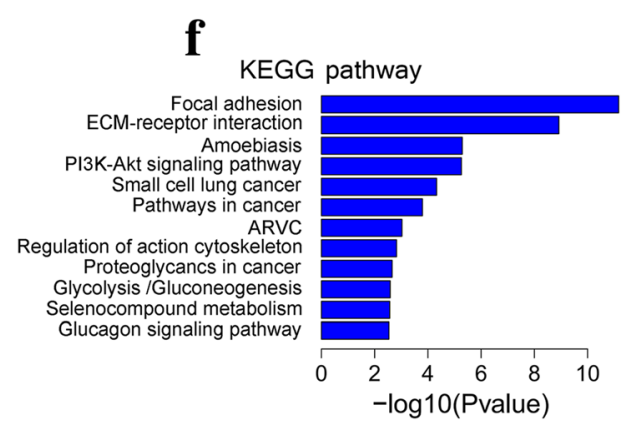

Fig. 6 Vitamin C treatment shifted the bladder cancer cell transcriptome. a Volcano plot figure for differentially expressed genes treated with vitamin C. b, c KEGG pathway and GO term analysis results for differentially expressed genes, respectively. $\mathbf{d}$ Representative GSEA enrichment plots for enriched gene sets. e Venn diagrams showing the overlap between elevated $5 \mathrm{hmC}$ peak-associated genes and differentially expressed genes. $\mathbf{f}$ KEGG pathway analysis results for overlapping genes 
hallmark in most cancers [9-12]. In contrast to $5 \mathrm{mC}$, $5 \mathrm{hmC}$ was found to be an important epigenetic mark of active genes and was mainly enriched in gene bodies [11]. These findings indicate that $5 \mathrm{hmC}$ might play an important role in tumorigenesis and progression. Various mechanisms may underlie $5 \mathrm{hmC}$ depletion in cancer, such as mutations in TETs and IDHs, which thus decrease the expression of TETs and IDHs [12, 21, 22]. Tumor hypoxia is also thought to be a reason for the loss of $5 \mathrm{hmC}$ by reducing TET activity [23]. Restoring $5 \mathrm{hmC}$ levels by overexpressing TET2 in melanoma cells, TET1 in breast cancer cells, and IDH1 in renal cancer cells demonstrated inhibitory effects in vitro and in vivo [11, 12, 24].

The inhibitory effects of vitamin $C$ both in vitro and in vivo have been reported in several cancers [25-28]. A number of clinical experiments have been conducted in advanced cancer patients, and they revealed that vitamin $C$ is a safe and well-tolerated micronutrient that can inhibit tumors [25, 26, 29]; however, the underlying therapeutic mechanism has remained largely undefined. One study suggested that vitamin $\mathrm{C}$ could inhibit nonsmall cell lung cancer (NSCLC) and glioblastoma (GBM) cells by increasing the levels of $\mathrm{H}_{2} \mathrm{O}_{2}$ and disrupting intracellular iron metabolism [26]. Other studies recently showed that vitamin $\mathrm{C}$ selectively killed KRAS and BRAF mutant colorectal cancer cells by targeting glyceraldehyde-3-phosphate dehydrogenase (GAPDH) [30].

As a cofactor, vitamin $\mathrm{C}$ can enhance the activity of $\mathrm{Fe}$ (II)-2-oxoglutarate dioxygenases, including TETs, leading to DNA demethylation [31]. Recent studies have shown that the suppression effects of vitamin $C$ partly result from the demethylation caused by activating TET. In leukemia, vitamin C suppressed hematopoietic stem cell (HSC) frequency and leukemogenesis by promoting TET activity $[16,17]$. Vitamin $\mathrm{C}$ restored $5 \mathrm{hmC}$ levels in melanoma and rebuilt the transcriptome in melanoma cells [28]. Another study also showed that vitamin C increased TET activity, leading to DNA demethylation in lymphoma cells independently of hydrogen peroxide [32]. Vitamin C also enhanced the antitumor effect of standard therapies. Vitamin $C$ abrogated cetuximab resistance mediated by mutant KRAS in human colon cancer cells [33]. Another study reported that vitamin $C$ enhanced the chemosensitivity of ovarian cancer and reduced the toxicity of chemotherapy [34]. Even at the physiological level, vitamin C also enhanced the effects of decitabine (5-aza-2'-deoxycytidine) in colorectal carcinoma, acute myeloid leukemia, breast carcinoma, and hepatocellular carcinoma cells [35]. Consistent with previous studies, we found that high-dose vitamin $\mathrm{C}$ could directly cause selective bladder cancer cell death and apoptosis in an $\mathrm{H}_{2} \mathrm{O}_{2}$-dependent manner and that low-dose vitamin $\mathrm{C}$ suppressed bladder cancer cell growth in an $\mathrm{H}_{2} \mathrm{O}_{2}$-independent manner that included $5 \mathrm{hmC}$ restoration.
In this study, we analyzed the transcriptome of bladder cancer cells after vitamin $C$ treatment. However, the results of RNA-seq and hMeDip-seq did not fit very well. A total of 482 genes were upregulated, 690 genes were downregulated following vitamin $\mathrm{C}$ treatment, and 503 genes correlated with changes in $5 \mathrm{hmC}$ levels. The mechanisms of how these $5 \mathrm{hmC}$ changes alter gene expression and contribute to the decreased malignancy of bladder cancer cells remain unclear and require further examination in the future. We also found that the IC50 of vitamin $\mathrm{C}$ for different types of cancers was variable. In this study, the IC50 of vitamin $\mathrm{C}$ for bladder cancer was $0.5 \mathrm{mM}$, and the IC50 for renal cancer cells was above $1 \mathrm{mM}$. In a study by Christopher B Gustafson, the IC50 of vitamin $C$ for melanoma cells was approximately $0.5 \mathrm{mM}$ [28]. Chen et al. compared the cytotoxicity of vitamin $\mathrm{C}$ on different cancer cells and found that different cell lines have various sensitivities [25]. The underlying mechanism of the inhibitory effect of vitamin $\mathrm{C}$ on different types of cancers requires additional study.

\section{Conclusions}

Our results suggest that the loss of $5 \mathrm{hmC}$ is a novel hallmark of bladder cancer with prognostic and outcome significance. We also demonstrated that vitamin $\mathrm{C}$ treatment can decrease the malignant phenotypes of bladder cancer in vitro and in vivo by partially increasing the global content of $5 \mathrm{hmC}$ and consequently altering the transcriptome. These results suggest that vitamin $\mathrm{C}$ could be a potential epigenetic treatment for bladder cancer and perhaps other types of cancer.

\section{Methods}

\section{Cell culture and treatment}

SV-HUC-1 normal human urinary epithelial cells were obtained from ATCC and cultured in F-12K medium (Gibco, USA). Human normal bladder primary epithelial cells Hum-u007 (obtained from iCell Bioscience Inc., Shanghai) were cultured in n ICell Primary Keratinocyte Culture System (PriMed-iCell-010). Bladder cancer cell lines T24 and 5637 cells were cultured in RPMI-1640 medium (Gibco, USA), and UMUC-3 and J82 cells were cultured in MEM medium (Gibco, USA). All bladder cancer cell lines were obtained from the Institute of Urology at Peking University (Beijing, China). All media contained $10 \%$ fetal bovine serum (Gemini, USA), penicillin $\mathrm{G}(100 \mathrm{U} / \mathrm{ml})$, and streptomycin $(100 \mu \mathrm{g} / \mathrm{ml})$ (Sigma-Aldrich, Germany). Cells were maintained as a monolayer culture at $37{ }^{\circ} \mathrm{C}$ in a humidified atmosphere containing $5 \% \mathrm{CO}_{2}$. After seeding on plates for $24 \mathrm{~h}$, the cells were treated with vitamin $\mathrm{C}$ (L-ascorbic acid, A4034, Sigma-Aldrich, St Louis, MO, USA) at different concentrations for varying durations. Catalase was obtained from Sigma (C1345). 


\section{Immunohistochemistry}

Surgical specimens were obtained from 135 patients diagnosed with bladder urothelial carcinoma at the Department of Urology, Peking University First Hospital, between 2010 and 2015. All patients signed informed consent, and the ethics committees of the Peking University First Hospital approved the protocol.

After fixing the tissues with $4 \%$ formalin and embedding them in paraffin wax, the tissues were cut into $5-\mu \mathrm{m} \mathrm{sec-}$ tions using a microtome. The sections were deparaffinized in xylene and rehydrated with graded concentrations of alcohol. Subsequently, the slides were treated with $3 \%$ $\mathrm{H}_{2} \mathrm{O}_{2}$ to block endogenous peroxidase activity and were heated $\left(95^{\circ} \mathrm{C}\right)$ for $2.5 \mathrm{~min}$ in citrate buffer $(10 \mathrm{mmol} / \mathrm{l}, \mathrm{pH}$ 6.0) for antigen retrieval. To reduce nonspecific binding, $10 \%$ normal goat serum was applied. Subsequently, the slides were incubated with anti-5hmC antibody (Active Motif, USA, 39769, 1:10,000) at $4{ }^{\circ} \mathrm{C}$ overnight. A PowerVision $^{\text {tw }}$ two-step histostaining reagent and 3,3-diaminobenzidine tetrahydrochloride substrate kit (ZSGB-Bio, China) were used to visualize the localization of the antigen according to the manufacturer's instructions.

The staining score of the $5 \mathrm{hmC}$ in tissues was evaluated by two independent pathologists by counting $5 \mathrm{hmC}$-positive nuclei at $0 \sim 10 \%, 11 \sim 30 \%, 31 \sim 50 \%$, and $>50 \%$ levels, and a positive rate $\geq 31 \%$ was defined as a high $5 \mathrm{hmC}$ level.

\section{Dot blot}

Genomic DNA was extracted from cultured cells using QIAamp DNA Mini Kits (Qiagen, Germany) according to the manufacturer's instructions. A Qubit Fluorometer (Life Technology, USA) was used to quantify the DNA concentration. DNA samples were diluted with $2 \mathrm{~N}$ $\mathrm{NaOH}$ and $10 \mathrm{mM}$ Tris. $\mathrm{Cl}$ at $\mathrm{pH} 8.5$ and then loaded onto a Hybond $\mathrm{N}+$ nylon membrane (GE Health, USA) using a 96-well dot blot apparatus (Bio-Rad, USA). After baking at $80{ }^{\circ} \mathrm{C}$ for $60 \mathrm{~min}$ and being blocked with $5 \%$ nonfat milk for $1 \mathrm{~h}$ at room temperature, the membrane was incubated in anti-5hmC (Active Motif, 39769) and anti-5mC antibodies (ZYMO RESEARCH, \#A3001-200) at $4{ }^{\circ} \mathrm{C}$ overnight and visualized by chemiluminescence. To ensure equal loading, the membrane was then stained with methylene blue.

\section{hMeDIP-seq}

One pair of bladder urothelial carcinoma and relative normal bladder tissues was used for hMeDip-seq. The sequencing libraries were prepared with $10 \mu \mathrm{g}$ of genomic DNA ligated to PE adaptors (Illumina, USA), which was followed by $5 \mathrm{hmC}$ antibody capture for immunoprecipitation. The hydroxymethylated fragments were amplified with 10-12 cycles using adaptor-specific primers (Illumina, USA) and quantified on an Agilent 2100 Bioanalyser before cluster generation and sequencing on a HiSeq 3000 according to the manufacturer's protocols.

\section{Identification of vitamin C-restored $5 \mathrm{hmC}$ peaks}

Briefly, the reads were aligned to the hg19 human genome (bowtie2, default parameters) and de-duplicated; unique reads were kept. Significantly, enriched regions were determined using model-based analysis with the ChIP-Seq (MACS) package (v.2.1.0, default settings). GO term and KEGG pathway analyses were performed with the Database for Annotation, Visualization, and Integrated Discovery (DAVID) program.

\section{Definition of enhancers}

The enhancers in adult normal bladder tissue were identified using Roadmap H3K27ac CHIP-seq data (GSM1013133 and GSM1059457). The enhancer was assigned to the nearest gene within a distance of $\sim 50 \mathrm{~kb}$ [36].

\section{RT-qPCR}

Total RNA was isolated from cell lines using the TRIzol reagent (Invitrogen, Thermo Fisher Scientific, Inc.). A total of $2 \mu \mathrm{g}$ of RNA was reverse-transcribed into cDNA using M-MLV reverse transcriptase (Promega, USA) and oligo (dT) 15 (Promega, USA) as a primer. Quantitative PCR was performed using SYBR $^{\circ}$ FAST qPCR Kits (KAPA Biosystems, USA) in a final volume of $10 \mu \mathrm{l}$ in the 7500 Fast Real-Time PCR System (Applied Biosystems, Thermo Fisher Scientific, Inc.). All primer pairs are shown in Table 3, and glyceraldehyde-3-phosphate dehydrogenase (GAPDH) served as the endogenous control. The expression of target mRNA was normalized to GAPDH according to the $\Delta \Delta$ Cq method.

\section{MTS cell viability assay, apoptosis assay, and colony formation assay}

Cell viability assays were assessed using the CellTiter $96^{\circ}$ AQ One Solution Reagent (Promega, USA) according to the manufacturer's instructions. An apoptosis assay was performed by FACS with Annexin V-FITC/PI staining. For colony formation assays, cells were seeded in 6-well plates at a density of 800 cells/well and cultured with different concentrations of vitamin $\mathrm{C}$ at $37^{\circ} \mathrm{C}$ for 7 days.

\section{Western blot analysis}

Total protein of cell lines was prepared with ice-cold radioimmunoprecipitation assay buffer (Sigma-Aldrich; Merck Millipore) and quantified using BCA protein assay reagent (Pierce Chemical Co., Rockford, IL, USA). Equal amounts of proteins were separated by SDS-PAGE and transferred to a polyvinylidene fluoride membrane. After blocking for $1 \mathrm{~h}$ with 5\% nonfat milk, the membranes were incubated overnight at $4{ }^{\circ} \mathrm{C}$ with Caspase-3 (Abcam, ab13847), Bcl-2 (Abcam, ab32124), Bcl-xl 
Table 3 Primer pairs for real-time PCR

\begin{tabular}{|c|c|c|}
\hline \multirow{2}{*}{$\frac{\text { Genes }}{\text { GAPDH }}$} & \multicolumn{2}{|c|}{ Sequence (5' to $\left.3^{\prime}\right)$} \\
\hline & Sense & GGTGAAGGTCGGAGTCAACG \\
\hline & Antisense & TGGGTGGAATCATATTGGAACA \\
\hline \multirow[t]{2}{*}{ TET1 } & Sense & AATGGAAGCACTGTGGTTTG \\
\hline & Antisense & ACATGGAGCTGCTCATCTTG \\
\hline \multirow[t]{2}{*}{ TET2 } & Sense & AATGGCAGCACATTGGTATG \\
\hline & Antisense & AGCTTCCACACTCCCAAACT \\
\hline \multirow[t]{2}{*}{ TET3 } & Sense & GAGGAGCGGTATGGAGAGAA \\
\hline & Antisense & AGTAGCTTCTCCTCCAGCGT \\
\hline \multirow[t]{2}{*}{ SVCT1 } & Sense & TCATCCTCCTCTCCCAGTACCT \\
\hline & Antisense & AGAGCAGCCACACGGTCAT \\
\hline \multirow[t]{2}{*}{ SVCT2 } & Sense & TCTITGTGCTTGGATITTCGAT \\
\hline & Antisense & ACGTTCAACACTTGATCGATTC \\
\hline \multirow[t]{2}{*}{$\mathrm{IDH} 1$} & Sense & TCCGTCACTTGGTGTGTAGG \\
\hline & Antisense & GGCTTGTGAGTGGATGGGTA \\
\hline \multirow[t]{2}{*}{$\mathrm{IDH} 2$} & Sense & TGAACTGCCAGATAATACGGG \\
\hline & Antisense & CTGACAGCCCCCACCTC \\
\hline \multirow[t]{2}{*}{ L2HGDH } & Sense & TCAAAAATTCATCCCTGAAATTACT \\
\hline & Antisense & CTACCAGATTTCCATCTCTATCCAG \\
\hline
\end{tabular}

(Abcam, ab32370), PARP (Abcam, ab191217), and beta-actin (Proteintech, 66009). After washing and incubating the membranes with secondary antibodies, signals were detected by applying ECL Western Blotting Detection Reagent (GE Healthcare Life Sciences).

\section{Mice xenograft model}

T24 cells $\left(1 \times 10^{6}\right.$ cells $)$ were resuspended in $100 \mathrm{ml}$ of PBS and subcutaneously injected into the axillary fossae in 4-week-old nude mice (BALB/c-nu). Tumor volume was calculated with the formula $V=0.5 a b^{2}$, where $a$ is the longest tumor axis, and $b$ is the shortest tumor axis. When the volume of the tumors reached approximately $150 \mathrm{~mm}^{3}$, mice with tumors were intraperitoneally injected with vitamin C (2 g/ $\mathrm{kg} /$ day $)$ or saline. The animal protocol was approved by the animal ethics committee of Peking University First Hospital.

\section{RNA-seq and gene set enrichment analysis}

The KAPA Stranded RNA-seq Library Preparation Kit was used to construct RNA-seq libraries according to the manufacturer's instructions. Sequencing reads were aligned to the hg19 human genome using the Tophat program (tophat v2.1.1) with the default parameters. Total read counts for each protein-coding gene were extracted using HTSeq (HTSeq version 0.6.0) and then loaded into the R-package DEseq2 to calculate the differentially expressed genes with FDR $<0.05$. GSEA was performed using $\mathrm{C} 2$ (curated gene sets) collections.

\section{Statistical analysis}

All data were evaluated with SPSS version 22.0 software (SPSS, Chicago, IL, USA). The Kaplan-Meier method and corresponding log-rank test were performed to determine the differences in postoperative survival rates. For univariate and multivariate analysis, the Cox regression method was used. Statistical significance was defined as $* P<0.05$ and ${ }^{* *} P<0.01$.

\section{Additional files}

Additional file 1: Figure S1. (A) $5 \mathrm{hmC}$ level scoring by $\mathrm{HC}$ staining $(0-10 \%, 11-30 \%, 30-50 \%$, and $>50 \%)$. (B) Dot blot assay of $5 \mathrm{hmC}$ levels of $\mathrm{J} 82$ and 5637 cells at varying vitamin C concentrations. (C) Dot blot assay of $5 \mathrm{mC}$ levels of $J 82$ and 5637 cells at varying vitamin C concentrations. (D) Dot blot assay of 5hmC levels of 786-O and A498 cells and MTS assay of cell viability at varying vitamin C concentrations. (TIF $3349 \mathrm{~kb}$ )

Additional file 2: Figure S2. (A) The relative transcription levels measured by RT-qPCR of TET1/2/3 in T24 cells treated with or without vitamin C. Statistical significance was determined by the Mann-Whitney $U$ test. (B) Western blot of apoptosis markers for T24 cells at varying vitamin C concentrations. (C) Cell viability measured with MTS of T24 and 5637 cells at varying vitamin C concentrations with or without catalase at $100 \mu \mathrm{g} / \mathrm{ml}$. Statistical significance was determined by the Mann-Whitney $U$ test. (D) Venn diagrams showing the overlap between decreased $5 \mathrm{hmC}$ peakassociated genes in bladder cancer and differentially expressed genes (left); KEGG pathway analysis results for overlapping genes (right). (E) Venn diagrams showing the overlap between decreased $5 \mathrm{hmC}$ peakassociated genes in bladder cancer; increased $5 \mathrm{hmC}$ peak-associated genes after vitamin $C$ treatment, and differentially expressed genes (left); KEGG pathway analysis results for overlapping genes (right). (TIF 980 kb)

Additional file 3: Table S1. List of differential expression genes in vitamin C treated and control T24 cells. (XLSX 224 kb)

Additional file 4: Table S2. KEGG_PATHWAY analysis of 1172 differential expression genes in Fig. 6b. (XLSX 78 kb)

\section{Abbreviations}

5hmC: 5-Hydroxymethylcytosine; 5mC: 5-Methylcytosine; hMeDIP: Hydroxymethylated DNA immunoprecipitation; IDH: Isocitrate dehydrogenases; IHC: Immunohistochemical staining; ITIH5: Inter-alphatrypsin inhibitor heavy chain family member 5; LATS2: Large tumor suppressor kinase 2; MeDIP: Methylated DNA immunoprecipitation; RND3: Rho family GTPase 3; SVCT: Sodium-dependent vitamin C transporters; TET: Ten-eleven translocation family dioxygenases; TIMP2: TIMP metallopeptidase inhibitor 2

\section{Funding}

This study was supported by grants from the National Natural Science Foundation of China (Grant Number: 81672546 to LZ; 81772703 to YG; and 81422035 and 81672541 to WC), the Clinical Features Research of Capital (Z151100004015173 to LZ), the Capital Health Research and Development of Special (2016-1-4077 to LZ), CAS Strategic Priority Research Program (XDA16010102 to WC), and the National Basic Research Programme (2016YFC0900303 to WC).

\section{Authors' contributions}

The experiments were conceived and designed by $W C, X L$, and $L Z$. DP and GG conducted the experiments. YG, YZ, SH, BG, YL, ZX, HH, ZH, GX, CZ, YS, and $Y Z$ participated in the data collection. Bioinformatics and statistical analyses of hMeDIP-seq and RNA-seq were performed by DP and GG. The manuscript was written and reviewed by DP, WC, XL, and $L Z$. All authors read and approved the final manuscript.

\section{Ethics approval and consent to participate}

This study has been approved by the ethics committees of the Peking University First Hospital. All samples and records were de-identified and 
anonymized prior to the study. Consent was obtained from all individuals for publication. No individual-level data are reported.

\section{Consent for publication}

Not applicable

\section{Competing interests}

The authors declare that they have no competing interests.

\section{Publisher's Note}

Springer Nature remains neutral with regard to jurisdictional claims in published maps and institutional affiliations.

\section{Author details}

'Department of Urology, Peking University First Hospital, Beijing 100034, China. ${ }^{2}$ Key Laboratory of Genomic and Precision Medicine, Beijing Institute of Genomics, Chinese Academy of Sciences, Beijing 100101, China. ${ }^{3}$ Institute of Urology, Peking University, Beijing 100034, China. ${ }^{4}$ National Urological Cancer Center, Beijing 100034, China. ${ }^{5}$ Urogenital Diseases (Male) Molecular Diagnosis and Treatment Center, Peking University, Beijing 100034, China. ${ }^{6}$ University of Chinese Academy of Sciences, Beijing 100049, China.

\section{Received: 23 February 2018 Accepted: 5 July 2018}

Published online: 13 July 2018

\section{References}

1. DeSantis CE, Lin CC, Mariotto AB, Siegel RL, Stein KD, Kramer JL, Alteri R, Robbins AS, Jemal A. Cancer treatment and survivorship statistics, 2014. CA Cancer J Clin. 2014;64:252-71.

2. Kamat AM, Hahn NM, Efstathiou JA, Lerner SP, Malmstrom PU, Choi W, Guo CC, Lotan Y, Kassouf W. Bladder cancer. Lancet. 2016;388:2796-810.

3. Alfred Witjes J, Lebret T, Compérat EM, Cowan NC, De Santis M, Bruins HM, Hernández V, Espinós EL, Dunn J, Rouanne M, et al. Updated 2016 EAU guidelines on muscle-invasive and metastatic bladder cancer. Eur Urol. 2017:71:462-75.

4. Baylin SB, Jones PA. A decade of exploring the cancer epigenome-biological and translational implications. Nat Rev Cancer. 2011;11:726-34.

5. Herman JG, Baylin SB. Gene silencing in cancer in association with promoter hypermethylation. N Engl J Med. 2003;349:2042-54.

6. Jones PA, Baylin SB. The fundamental role of epigenetic events in cancer. Nat Rev Genet. 2002;3:415-28.

7. Hanahan D, Weinberg RA. Hallmarks of cancer: the next generation. Cell. 2011;144:646-74.

8. Tahiliani M, Koh KP, Shen Y, Pastor WA, Bandukwala H, Brudno Y, Agarwal S, lyer LM, Liu DR, Aravind L, et al. Conversion of 5-methylcytosine to 5hydroxymethylcytosine in mammalian DNA by MLL partner TET1. Science. 2009;324:930-5

9. Yang H, Liu Y, Bai F, Zhang JY, Ma SH, Liu J, Xu ZD, Zhu HG, Ling ZQ, Ye D, et al. Tumor development is associated with decrease of TET gene expression and 5-methylcytosine hydroxylation. Oncogene. 2013;32:663-9.

10. Jin SG, Jiang Y, Qiu R, Rauch TA, Wang Y, Schackert G, Krex D, Lu Q, Pfeifer GP. 5-hydroxymethylcytosine is strongly depleted in human cancers but its levels do not correlate with IDH1 mutations. Cancer Res. 2011;71:7360-5.

11. Hore TA, von Meyenn F, Ravichandran M, Bachman M, Ficz G, Oxley D, Santos F, Balasubramanian S, Jurkowski TP, Reik W. Retinol and ascorbate drive erasure of epigenetic memory and enhance reprogramming to naive pluripotency by complementary mechanisms. Proc Natl Acad Sci U S A. 2016;113:12202-7

12. Lian CG, Xu Y, Ceol C, Wu F, Larson A, Dresser K, Xu W, Tan L, Hu Y, Zhan Q et al. Loss of 5-hydroxymethylcytosine is an epigenetic hallmark of melanoma. Cell. 2012:150:1135-46.

13. Munari E, Chaux A, Vaghasia AM, Taheri D, Karram S, Bezerra SM, Gonzalez Roibon N, Nelson WG, Yegnasubramanian S, Netto GJ, et al. Global 5hydroxymethylcytosine levels are profoundly reduced in multiple genitourinary malignancies. PLoS One. 2016;11:e0146302.

14. Li J, Xu Y, Zhang Z, Zhang M, Zhang Z, Zhang F, Li Q. Expression and clinical significance of $5 \mathrm{hmC}$ in bladder urothelial carcinoma. Chin J Cel Mol Immunol. 2016:32:232-5.

15. Cadet J, Wagner JR. TET enzymatic oxidation of 5-methylcytosine, 5hydroxymethylcytosine and 5-formylcytosine. Mutat Res Genet toxicol Environ Mutagenesis. 2014;764-765:18-35.
16. Agathocleous M, Meacham CE, Burgess RJ, Piskounova E, Zhao Z, Crane GM, Cowin BL, Bruner E, Murphy MM, Chen W, et al. Ascorbate regulates haematopoietic stem cell function and leukaemogenesis. Nature. 2017;549:476

17. Cimmino L, Dolgalev I, Wang Y, Yoshimi A, Martin GH, Wang J, Ng V, Xia B, Witkowski MT, Mitchell-Flack M, et al. Restoration of TET2 function blocks aberrant self-renewal and leukemia progression. Cell. 2017;170:1079-95.

18. Taylor SE, Li YH, Smeriglio P, Rath M, Wong WH, Bhutani N. Stable 5hydroxymethylcytosine ( $5 \mathrm{hmC}$ ) acquisition marks gene activation during Chondrogenic differentiation. J Bone Miner Res. 2016;31:524-34.

19. He XB, Kim M, Kim SY, Yi SH, Rhee YH, Kim T, Lee EH, Park CH, Dixit S, Harrison $\mathrm{FE}$, et al. Vitamin $\mathrm{C}$ facilitates dopamine neuron differentiation in fetal midbrain through TET1- and JMJD3-dependent epigenetic control manner. Stem Cells. 2015:33:1320-32.

20. Blaschke K, Ebata KT, Karimi MM, Zepeda-Martinez JA, Goyal P, Mahapatra S, Tam A, Laird DJ, Hirst M, Rao A, et al. Vitamin C induces Tet-dependent DNA demethylation and a blastocyst-like state in ES cells. Nature. 2013;500:222-6.

21. Ko M, Huang Y, Jankowska AM, Pape UJ, Tahiliani M, Bandukwala HS, An J, Lamperti ED, Koh KP, Ganetzky R, et al. Impaired hydroxylation of 5methylcytosine in myeloid cancers with mutant TET2. Nature. 2010;468:839-43.

22. Figueroa ME, Abdel-Wahab O, Lu C, Ward PS, Patel J, Shih A, Li Y, Bhagwat $\mathrm{N}$, Vasanthakumar A, Fernandez HF, et al. Leukemic IDH1 and IDH2 mutations result in a hypermethylation phenotype, disrupt TET2 function, and impair hematopoietic differentiation. Cancer Cell. 2010;18:553-67.

23. Thienpont B, Steinbacher J, Zhao H, D'Anna F, Kuchnio A, Ploumakis A Ghesquiere B, Van Dyck L, Boeckx B, Schoonjans L, et al. Tumour hypoxia causes DNA hypermethylation by reducing TET activity. Nature. 2016:537:6

24. Hsu CH, Peng KL, Kang ML, Chen YR, Yang YC, Tsai CH, Chu CS, Jeng YM, Chen YT, Lin FM, et al. TET1 suppresses cancer invasion by activating the tissue inhibitors of metalloproteinases. Cell Rep. 2012;2:568-79.

25. Chen Q, Espey MG, Sun AY, Pooput C, Kirk KL, Krishna MC, Khosh DB, Drisko J, Levine M. Pharmacologic doses of ascorbate act as a prooxidant and decrease growth of aggressive tumor xenografts in mice. Proc Natl Acad Sci U S A. 2008:105:11105-9.

26. Schoenfeld JD, Sibenaller ZA, Mapuskar KA, Wagner BA, Cramer-Morales KL, Furqan M, Sandhu S, Carlisle TL, Smith MC, Abu Hejleh T, et al. O2- and $\mathrm{H} 2 \mathrm{O} 2$-mediated disruption of Fe metabolism causes the differential susceptibility of NSCLC and GBM cancer cells to pharmacological ascorbate. Cancer Cell. 2017;31:487-500.

27. Miles SL, Fischer AP, Joshi SJ, Niles RM. Ascorbic acid and ascorbate-2phosphate decrease HIF activity and malignant properties of human melanoma cells. BMC Cancer. 2015;15:867.

28. Gustafson CB, Yang C, Dickson KM, Shao H, Van Booven D, Harbour JW, Liu ZJ, Wang G. Epigenetic reprogramming of melanoma cells by vitamin C treatment. Clin Epigenetics. 2015:7:51

29. Stephenson CM, Levin RD, Spector $T$, Lis CG. Phase I clinical trial to evaluate the safety, tolerability, and pharmacokinetics of high-dose intravenous ascorbic acid in patients with advanced cancer. Cancer Chemother Pharmacol. 2013;72:139-46.

30. Yun J, Mullarky E, Lu C, Bosch KN, Kavalier A, Rivera K, Roper J, Chio II, Giannopoulou EG, Rago C, et al. Vitamin C selectively kills KRAS and BRAF mutant colorectal cancer cells by targeting GAPDH. Science. 2015;350:1391-6.

31. Loenarz C, Schofield CJ. Expanding chemical biology of 2-oxoglutarate oxygenases. Nat Chem Biol. 2008:4:152-6.

32. Shenoy N, Bhagat T, Nieves E, Stenson M, Lawson J, Choudhary GS, Habermann T, Nowakowski G, Singh R, Wu X, et al. Upregulation of TET activity with ascorbic acid induces epigenetic modulation of lymphoma cells. Blood Cancer J. 2017:7:e587.

33. Jung SA, Lee DH, Moon JH, Hong SW, Shin JS, Hwang IY, Shin YJ, Kim JH, Gong EY, Kim SM, et al. L-ascorbic acid can abrogate SVCT2-dependent cetuximab resistance mediated by mutant KRAS in human colon cancer cells. Free Radic Biol Med. 2016:95:200-8.

34. Ma Y, Chapman J, Levine M, Polireddy K, Drisko J, Chen Q. High-dose parenteral ascorbate enhanced chemosensitivity of ovarian cancer and reduced toxicity of chemotherapy. Sci Transl Med. 2014;6:222ra18.

35. Liu M, Ohtani H, Zhou W, Orskov AD, Charlet J, Zhang YW, Shen H, Baylin SB, Liang G, Gronbaek K, et al. Vitamin C increases viral mimicry induced by 5-aza-2'-deoxycytidine. Proc Natl Acad Sci U S A. 2016;113:10238-44.

36. Chepelev I, Wei G, Wangsa D, Tang Q, Zhao K. Characterization of genome-wide enhancer-promoter interactions reveals co-expression of interacting genes and modes of higher order chromatin organization. Cell Res. 2012;22:490-503. 